Brit. J. industr. Med., 1959, 16, 23.

\title{
TOXIC SOLVENTS: A REVIEW
}

BY

\author{
ETHEL BROWNING
}

The literature on toxic solvents increases in volume from year to year, almost from day to day, both concerning those already known and closely investigated by a multitude of observers and also those new chemical compounds constantly being introduced in industrial processes.

One of the most striking features of recent developments has been the extension of knowledge afforded by new and sometimes very complex scientific methods of examining the physiological response, metabolic processes, and detoxication mechanisms of animals and human beings subjected to the toxic effects of certain solvents; the detection and identification of their presence in mixtures; the chemical relationship of members of the different groups; and the measurement of the concentrations of their vapour in the atmosphere of workrooms. With regard to new solvents which have been produced in recent years, it is fortunate that the majority of them, investigated by modern methods, have proved on the whole less hazardous, particularly from the viewpoint of chronic systemic poisoning, than some of the older substances whose toxicity was revealed by involuntary human experiment.

\section{GENERAL DEVELOPMENTS \\ Experimental Physiology}

Animal experiments, while undoubtedly useful in providing evidence of the nature and extent of the biological injury inflicted on living tissue by poisonous chemical substances, have certain disadvantages. Among these are the differences in response between animals and human beings and between different species of animals, due to some extent to differences in their metabolic processes; variations in the toxic effect of a compound according to its route of administration; and the fact that if the effects of long-continued exposures in conditions approximating to those of industrial exposure are to be accurately determined, the investigations must necessarily be prolonged and intricate.

The usual method of expressing the acute toxicity of a solvent is the L.D. 50, the dose in milligrams per kilogram of body weight which kills one half of the animals under investigation. Comparisons can be made of the toxicity relative to that of other solvents, and the variation in response according to the route of administration. This is exemplified in the following account of an experiment undertaken to determine the toxicity, and therefore the suitability of a solvent for toxicological test of various compounds (E. F. Edson, personal communication).

The solvent under examination was tetrahydrofurfuryl alcohol, a colourless liquid boiling at $178^{\circ} \mathrm{C}$.<smiles>OCC1CCCO1</smiles>

Administered intraperitoneally to rats its L.D. 50 was approximately $1,000 \mathrm{mg}$. $/ \mathrm{kg}$., with no appreciable toxic effects at $500 \mathrm{mg}$. $/ \mathrm{kg}$. Oral administration gave a similar type of toxic effect (weakness, narcosis, tachycardia, and urinary incontinence) occurring between 1,000 and $2,000 \mathrm{mg}$. $/ \mathrm{kg}$., but the L.D. 50 by this route was $4,000 \mathrm{mg}$. $/ \mathrm{kg}$., four times that of the intraperitoneal route, while the subcutaneous lethal dose was $2,000 \mathrm{mg} . / \mathrm{kg}$. From these estimates a comparison could be made with the toxicity of propylene glycol administered by similar methods. Propylene glycol proved to be the less toxic both orally and intraperitoneally, but the margin between the non-toxic and the lethal doses was less than with tetrahydrofurfuryl alcohol.

In determining acute toxicity by inhalation the L.C. 50 (the concentration of the gas or vapour that will kill one half of the animals in a given time), or the L.T. 50 (the time required to kill one half of the animals by a given concentration of the gas or vapour) is used (Gross, Schrenk, and Walmer, 1956).

Investigations of chronic toxicity by animal experiments are, however, long-term studies requiring two or more years, different species of animals, and detailed morphological examinations of organs and tissues.

An assessment of toxicity based on the L.D. 50 may differ considerably from that based on chronic exposure. This can be seen clearly if the classification of toxicity of some solvents given by Fairhall (1957) 
on the former basis is translated into a corresponding classification estimated from the maximum allowable concentrations (or threshold limit values) published in 1958 by the American Conference of Governmental Industrial Hygienists. In Fairhall's classification, Class $I$ is designated as " extremely toxic", Class II as "very toxic", Class III as " moderately toxic", and Class IV as "slightly or nearly non-toxic". In the threshold limit values, a level of 1 to 5 p.p.m. may be interpreted as corresponding to Class I, 5 to 100 p.p.m. as Class II, 100 to 500 p.p.m. as Class III, and 500 p.p.m. upwards as Class IV. The table illustrates the difference in classification of some solvents as estimated according to their acute or chronic toxicity.

\begin{tabular}{|c|c|c|}
\hline Substance & $\begin{array}{c}\text { Threshold Limit } \\
\text { Value }\end{array}$ & L.D. 50 Value \\
\hline $\begin{array}{l}\text { Butyl alcohol } \\
\text { Butylamine } \\
\text { I-chloronitropropane } \\
\text { Cresol (all isomers) } \\
\text { Diethyl sulphate } \\
\text { Dimethyl sulphate } \\
\text { Dioxane } \\
\text { Ethylenediamine }\end{array}$ & $\begin{array}{l}\text { Class III } \\
\text { Class I } \\
\text { Class II } \\
\text { Class I } \\
\text { Class II } \\
\text { Class I } \\
\text { Class III } \\
\text { Class II }\end{array}$ & $\begin{array}{c}\text { Class IV } \\
\text { Class III } \\
\text { Class I } \\
\text { (p-cresol) Class IV } \\
\text { Class III } \\
\text { Class IV } \\
\text { Class IV } \\
\text { Class IV }\end{array}$ \\
\hline
\end{tabular}

The great improvements in the technique of inhalation experiments have been largely responsible for the development of one of the most useful guides to the control of health hazards at present available, namely, the annual publication already mentioned of the threshold limit values, or maximum allowable concentrations, of contaminants above which workers should not be exposed for an eight-hour working day. While these values are not offered as a "fine line" between safe and dangerous concentrations they do represent, based as they are on both industrial experience and also animal experimentation by observers in practically every country, a picture of the potentially hazardous environmental situation, and a comparison of the relative toxicity of a large number of solvents. Their number increases with every annual review, and in the light of new experience the values of some of those previously published are re-assessed and their levels altered either upwards or downwards in the light of the most recent evidence.

The most striking example of lowering of the threshold limit value during recent years is benzene, which has been reduced from 100 p.p.m. in 1926 and 35 p.p.m. in 1949 to 25 p.p.m. in 1957. This last reduction was based not on animal experiments but on the industrial experience of the death of a worker exposed to this level (Greenburg and Moskowitz, 1945). Other recent reductions are those of butyl cellosolve from 200 to 50 p.p.m. and carbon tetrachloride from 100 p.p.m. to 25 p.p.m.
Among new compounds of relatively high toxicity added to the list during the last two years are decaborane ( 0.05 p.p.m.), furfural ( 5 p.p.m.), and isopropylamine ( 5 p.p.m.).

\section{The Metabolism and Detoxication of Solvents}

A feature of some interest on which the attention of many investigators has been focused in recent years is the metabolic transformation of various toxic substances within the body, and the relation of these metabolic products to their injurious effects on particular organs and tissues. These investigations are not in themselves of very recent development; the formation of conjugated sulphates during the metabolism of benzene was fully described by Yant, Schrenk, Sayers, Horvath, and Reinhart as early as 1936. Knowledge of these processes has, however, been greatly facilitated by the technical application of spectrophotometric methods, chromatography, and the use of radioactive tracers.

Spectrophotometric Methods. - Spectrophotometric determinations of certain halogenobenzenes (fluoro-, chloro-, bromo-, and iodo-benzene) have been described by Azouz, Parke, and Williams (1952), using the absorption spectra of these substances in ethanol and selecting suitable wave-lengths and extinction of absorption bands. By this method it was possible to compare the quantitative aspects of the metabolism of these substances with that of benzene itself.

Paper Chromatography.-This is a suitable method of estimating metabolites directly from body fluids. About 5 to $10 \mu \mathrm{g}$. of the fluid under investigation is placed in spots on a base drawn on the chromatographic paper, the lower edge of which is placed in contact with a composite solvent mixture consisting of one liquid which covers the paper (the stationary phase) and another which moves across it (the mobile phase). Each component of the spot flows in the mobile phase across the paper at a different speed. The position of the spot is determined, after removal of the solvent, by spraying the paper with a substance forming a coloured compound with the component. Each component is identified by the ratio of the distances from the base line travelled by the component and by the solvent.

Radioactive Tracers.-Quantitative measurements may be made by means of optical density, ultraviolet spectrophotometry, or using radioactive tracers. The technique of using radioactive tracers for identifying the nature, fate, and relative amount of excretion of metabolites of toxic substances (Popják, 1950) is well exemplified in the experiments on benzene described in detail by Parke and Williams (1953). They administered ${ }^{14} \mathrm{C}$-labelled benzene by stomach tube, and the radioactivity of the 
urine, the tissues, and the expired $\mathrm{CO}_{2}$ was compared with that of known amounts of labelled benzene. It was thus found possible to estimate the amount of benzene eliminated in the expired air (about $45 \%$ in two days, of which $43 \%$ was unchanged and about $1.5 \%$ in the form of $\mathrm{CO}_{2}$ ) and the amount eliminated in the urine (nearly $35 \%$, consisting mainly of conjugated phenols), and to identify other urinary metabolites such as quinol. catechol, hydroxyquinol, and a small amount of phenyl-mercapturic acid. Nearly $80 \%$ of the dose of benzene was excreted in the expired air and urine in two to three days, while the remainder was eliminated slowly, about $5 \%$ remaining after this time in the tissues generally as metabolites of benzene.

Considerable light has also been thrown by this method on the metabolism of carbon tetrachloride (McCollister, Beamer, Atchison, and Spencer, 1951). It was found that about $50 \%$ of the $\mathrm{CCl}_{4}$ absorbed was later eliminated in the expired air, and that although the blood concentration at the end of exposure to 46 p.p.m. was low, there were considerable amounts of radioactive carbon in the urine as an unidentifiable compound, possibly an organic chloride. As Elkins (1954) has remarked, if this substance could be identified and its separation from inorganic chlorides achieved, we might have a method of evaluating $\mathrm{CCl}_{4}$ exposure by analysis of urine.

These investigations of the way in which the enzymatic processes of the body attempt to deal with toxic substances introduced from outside are being carried out with increasing frequency and scope, and their results provide an insight into the biological function of detoxication. Several industrial solvents have been examined by these methods and their ultimate fate in the body was described by Truhaut (1953b). A comprehensive table of end-products, in the form of urinary metabolites of a large number of substances, has been drawn up by L. J. Sciarini in Appendix II of Fairhall's “Industrial Toxicology ".

Such investigations have also gone far towards explaining the difference in toxicity of members of the same chemical group. The extreme toxicity of benzene to the haemopoietic organs following chronic exposure, contrasted with the relative nontoxicity in this respect of another aromatic hydrocarbon, cyclohexane, is due to the final metabolism of benzene to phenolic compounds, including pyrocatechol and hydroquinol, which are mitotic poisons with a special predilection for proliferating tissues such as the bone marrow; cyclohexane, on the other hand, is transformed first into cyclohexanone and finally into adipic acid, which has no special affinity for the haemopoietic tissues (Treon, Crutchfield, and Kitzmiller, 1943; Fabre, Truhaut, and Péron, 1952). Similarly, the higher toxicity of ethylene glycol compared with that of its group relative, propylene glycol, both used as solvents for cellulose varnishes, is explained by differences in their metabolism. Ethylene glycol is transformed first into glycollic acid, then into oxalic acid, which has an injurious effect on the kidneys, whereas propylene glycol gives rise only to a normal product of glucide metabolism, probably lactic acid, which is quite innocuous (Truhaut, 1953a). The formation of these harmless metabolites is regarded as a process of detoxication of which the principal site is believed to be the liver, with assistance from the endocrine glands, especially the thyroid and the adrenal cortex. In the transformation of trichloroethylene into trichloracetic acid, the lungs and spleen are also active in detoxication (Grandjean, Munchinger, Turrian, Haas, Knoepfel, and Rosenmund, 1955).

\section{Estimations of Atmospheric Concentrations}

Many methods have been used for estimating atmospheric concentrations of mixed contaminants, and though they have been developed to a high degree of accuracy, the separation of an individual constituent of a mixture, for example of aromatic hydrocarbons, is a tedious and time-consuming procedure. In general, colorimetric analysis is used for the determination of organic vapours by the formation of a coloured product which can be matched against a known standard. In most of such tests a measured volume of air is drawn through either a test paper or an impregnated silica gel. A description of this colorimetric method for the detection of 12 of the more common industrial contaminants was published in 1939 by the Department of Scientific and Industrial Research; this method is still in use, but it has a limited value for some of the solvents on account of its insufficient sensitivity for the levels now considered as the lower toxic limits. A method for the rapid determination of some aromatic hydrocarbons (benzene and its homologues) in air, by means of a stable directindicating gel utilizing a sulphuric-formaldehyde reagent, was described by Hubbard and Silverman in 1950. The qualitative colour differentiation was sensitive to benzene (reddish brown), toluene (flesh pink to lavender), and xylene (yellow to pink), and interference from other solvent vapours present was minimal when a benzene concentration of 50 p.p.m. was superimposed on concentrations of solvents such as butyl alcohol, butyl acetate, and ethyl acetate which gave slight yellow coloration under saturated conditions. The impregnated silica gel method lends itself to the technique introduced by Tiselius in 1943 and known as the "displacement "technique, which may be used for various analytical purposes. 
It has been described by Övrum (1956) in the determination of atmospheric benzene. The principle is that of adsorption of the fluid mixture to be analysed on a column of silica gel, with subsequent displacement by a substance which is more strongly adsorbed than any of the components of the mixture. The adsorbed benzene is forced out of the gel by absolute alcohol and collected in a volumetric flask, then identified and measured by an ultra-violet spectrophotometer, using absolute alcohol as the spectroscopic solvent. Concentrations ranging from 0.003 to $1.28 \mathrm{mg}$. per litre were determined without difficulty by this method. Other physical methods of estimation of atmospheric concentrations include those of catalysed combustion, vapour pressure, absorption spectrophotometry, and chromatography.

Catalysed Combustion.-In catalysed combustion over a heated platinum wire, the temperature increase of the wire is measured electrically; the method is sensitive enough for many organic substances-hydrocarbons, alcohols, ethers, and esters (Strafford, 1949).

Vapour Pressure Method.-In the vapour pressure method, organic vapours are condensed by means of a freezing agent and then allowed to warm to room temperature and the pressure measured with a manometer (Couchman and Schulze, 1939; Silverman, Reece, and Drinker, 1939).

Absorption Spectrophotometry.-This method is ideally suited for automatic recording, and although the necessary instruments are costly and need considerable servicing, they have already been applied to substances such as carbon disulphide, aniline, trichloroethylene, and perchloroethylene, and will no doubt be more generally used in the future.

Gas Chromatography.-Gas chromatography is specially suitable for estimating the separate components of a solvent mixture. The size of sample required is very small, amounting to less than $5 \mathrm{ml}$. for a gas or less than $20 \mathrm{ml}$. for a liquid. The solvent is carried, by means of a carrier gas, which may be a stream of helium, argon, hydrogen, nitrogen, or carbon dioxide, flowing at a controlled rate, on to a stationary phase, which may be a solid such as alumina, silica, or charcoal, or a liquid supported on a highly porous inert material such as diatomaceous earth (Talvitie, 1958). Those components with the highest solubility in this stationary phase are held longest on the partition column, so that each component emerges separately in the carrier gas and is determined quantitatively by a detector. Various types of detector are available, depending upon which property of the carrier gas is to be measuredthermal conductivity, gas density, or flame temper- ature if the carrier gas is combustible. The newest detector, depending on measurement of the ionization of the current induced by Beta rays, can detect less than 1 p.p.m. of solvent. The peak area of each component as it appears on a strip chart recorder is a measure of its concentration and the analysis has an accuracy of $0.05 \%$.

\section{INDIVIDUAL SOLVENTS}

The Aromatic Hydrocarbons

Among the aromatic hydrocarbons benzene is unique in its specific attack on haemopoietic tissue. The metabolic studies already described have shown that none of its homologues produces end-products with a special affinity for bone marrow, though one, p-tertiary butyl toluene, which will be described in detail later, is said to have produced a peripheral blood disturbance suggestive of a "benzene" effect. One of the main features of the more recent investigations of solvents of this group has been the search for substances which might replace this technically valuable but most toxic member.

That the serious effects of benzene have not yet by any means been completely prevented is emphasized by a recent report (Savilahti, 1956) of more than 100 cases of chronic poisoning in one shoe factory in Germany where the air concentrations were later estimated at 400 p.p.m. Suspicion of toxic exposure was only aroused when two of the workers were admitted to hospital suffering from aplastic anaemia. Blood examinations of 147 workers were then made, with the result that 47 showed leucopenia (under 3,000 white cells per c.mm. in 18 cases), 51 anaemia, and 91 thrombocytopenia. Savilahti, in common with other German investigators, regards thrombocytopenia as the most frequent finding in chronic benzene poisoning. Although he found no definite correlation between a low thrombocyte count and a tendency to haemorrhage, he observed that the best prognosis was in those cases where thrombocytopenia was the only abnormality of the blood picture.

In the search for substances to replace benzene many solvents with similar technical properties have been suggested; they include trichloroethylene, perchloroethylene, the solvent naphthas, cyclohexane, and the various homologues of benzene, xylene, toluene, ethyl benzene, and certain commercial alkyl benzenes. Some of these have technical and economic disadvantages, while others may possibly contain small amounts of benzene as an impurity. This last possibility applies to the best known homologues of benzene, xylene and toluene, and to the light and heavy solvent naphthas. The light naphthas may consist of $70 \%$ xylene, $5 \%$ 
toluene, and $25 \%$ cumene, and the heavy variety of $35 \%$ xylene and $50 \%$ cumene (Albahary, 1955). According to Elkins and Pagnotto (1956), analysis of eight samples of solvent naphtha indicated benzene concentrations from 0.6 to about $7 \%$. The investigations of Fabre et al. in 1952 led them to conclude, on the basis of animal experiments, that cyclohexane had no injurious effect on the blood and was therefore a suitable substitute for benzene. It was later announced by Tara (1953) that two men and a woman employed in processes involving the use of cyclohexane had shown peripheral blood changes similar to those of chronic benzene poisoning. Truhaut replied to these observations by stating that his examinations of samples of commercial cyclohexane had revealed the presence of benzene in amounts varying from 1 to $3.6 \mathrm{~g}$. per $100 \mathrm{ml}$. and that in using cyclohexane as a substitute for benzene its freedom from benzene as an impurity must be rigorously controlled.

Among the less well-known homologues of benzene which have recently undergone investigation are certain alkyl derivatives, including iso-propyl benzene (cumene), n-propyl, n-butyl, methyl, trimethyl, tetra-methyl, amyl, ethyl, propyl, and methyl-propyl benzenes, styrene, $\alpha$-methyl styrene, and vinyl toluene. These substances have been tested by Gerarde (1956) with a view to determining whether they possess the benzene-like specificity for haemopoietic injury, and some of them for their neurotoxicity relative to that of benzene (Furnas and Hine, 1958). These commercial alkyl benzenes, used extensively as solvents for fats, resins, and rubber, are petrol derivatives obtained by catalytic hydrogenation of petroleum products. In Gerarde's experiments they were administered to animals subcutaneously in olive oil, while control groups received benzene in olive oil or olive oil alone. The criteria of injury were the general condition, peripheral leucocyte count, haematocrit value, marrow nucleated cell count, estimation of marrow ribonucleic acid and deoxyribonucleic acid, and microscopic examination of tissues and organs. It was found that as a group the alkyl derivatives showed a much lower toxicity in all these respects than benzene itself, particularly with regard to the blood findings. Whereas the benzene-treated animals showed leucopenia and a decrease in the marrow nucleated count and nucleic acid, those given the same dosage of toluene, ethyl benzene, n-propyl benzene, and n-butyl benzene showed no abnormality of any of these haemopoietic features.

Similar results were obtained by Wolf, Rowe, McCollister, Hollingsworth, and Oyen (1956), who gave animals repeated inhalations over a period of six months. They found that ethyl benzene, iso- propyl benzene, styrene, $\alpha$-methyl styrene, and vinyl toluene were all less toxic than benzene and that none possessed its specific dyshaemopoietic effect.

The lack of toxic effect of iso-propyl benzene on the blood of animals was confirmed by Fabre, Truhaut, Bernuchon, and Loisillier (1954), but their biological investigations revealed a slow elimination, and therefore a possible cumulative action of this solvent. Paper chromatography showed the presence of some not fully identified phenolic derivatives in the bone marrow, brain, spleen, and adrenals; these organs showed no significant lesions, but in $10 \%$ of the animals there was some tubular nephritis. This is a very interesting finding, in view of the fact that the metabolic products of most of the alkyl derivatives are alcohols and carboxylic acids, which are of a low order of toxicity, unlike the phenolic compounds of benzene metabolism.

The acute effects on the central nervous system of the aromatic hydrocarbon solvents are well known, and the opinion has long been held that xylene and toluene are in fact more potent narcotics than benzene.

An attempt to confirm this by studying their effects on nervous tissue, and whether other derivatives of the series have a similar neurotoxic effect has recently been carried out by Furnas and Hine (1958). Large sublethal doses of the materials tested, which included benzene, toluene, xylene, ethyl toluene, methyl styrene, cumene, $\mathrm{p}$ - and $\mathrm{m}$ tertiary butyl toluene, were administered to rats by injection; the degree of injury was assessed by histological examination of nervous tissues, by electroencephalography, and by oxygen uptake studies on brain tissue slices. It was confirmed that benzene was the least toxic in this respect and toluene the next, while the toxicity of the substituted toluenes increased from p-methyl up to p-tertiary butyl, the last causing marked cerebral stimulation followed by profound depression. Histological changes in the central nervous system were not found, even with p-tertiary butyl toluene, contrary to the findings in an earlier investigation by Ungar, Hine, Kodama, and Anderson (1955), who used special nerve tissue stains by which they were able to demonstrate deposits of metachromatic material in the glial elements of the brain and spinal cord, destruction of neurons, and patchy demyelination.

Tertiary Butyl Toluene.-As a result of the investigations of Hine, Ungar, Anderson, Kodama, Critchlow, and Jacobsen in 1954, and Furnas and Hine in 1958, p-tertiary butyl toluene appears to be incriminated as both a neurotoxic poison, affecting primarily the white matter, and also to some extent 
as a dyshaemopoietic agent with an effect resembling that of benzene though not so severe.

p-Tertiary butyl toluene (1-tert-butyl-4-methylbenzene), $\mathrm{CH}_{3} \mathrm{C}\left(\mathrm{CH}_{3}\right)_{3}$ is a liquid with a distinctive odour (B.P. $192 \cdot 8^{\circ}$ C., sp. gr. 0.8573). Saturated air at room temperature contains 850 p.p.m. It is used chiefly as a stable, moderately high-boiling solvent, of high purity, for the preparation of resins.

Toxic Effects on Animals.-The results of intragastric administration as well as of inhalation of high concentrations show that the acute toxic effect of p-tertiary butyl toluene is greater than that of benzene, toluene, and cumene. The L.D. 50 for benzene is 10,000 p.p.m., for toluene 5,000 p.p.m., and for cumene 2,000 p.p.m.; that of p-tertiary butyl toluene is approximately 180 p.p.m.

Single exposures to inhalation of concentrations from 60 to 1,500 p.p.m. for periods varying from one to eight hours showed that the higher concentrations affected chiefly the central nervous and respiratory systems, causing paralysis of both spastic and flaccid types, and in some animals convulsions and epileptiform seizures. The lowest concentration at which muscular weakness appeared was 90 p.p.m. after an exposure of about six hours. Respiratory disturbances appeared at 60 p.p.m. and extreme immediate dyspnoea at 1,500 p.p.m. Short repeated exposures to saturated vapour concentrations (about 850 p.p.m.) also produced impairment of muscle tone and at relatively low concentrations degenerative lesions in the brain and spinal cord were observed at necropsy.

Animals repeatedly exposed showed a decrease in erythrocytes and leucocytes in the peripheral blood.

Toxic Effects on Human Beings.- The effects of p-tertiary butyl toluene on some workers employed in a pilot-scale production of this substance, as well as some sensory studies on volunteers, have been described by Hine et al. (1954). The concentrations to which the workmen were exposed were only about 10 p.p.m. during normal operations, but at times, owing to spillage or improper operation of the exhaust system, they might rise to 136 p.p.m. while 350 p.p.m. were found at the opening of the centrifuge when it was being hand scraped. Some of the men showed a low-grade transient intoxication, with symptoms of disturbance of the cardiovascular and central nervous systems-decreased blood pressure, increased pulse rate, tremor, and anxiety. There were also decreased levels of haemoglobin and red cells, leucopenia, and abnormal differential counts. Sensory response studies showed that exposure for five minutes to concentrations of 5 to 160 p.p.m. caused moderate eye irritation at
80 p.p.m. and giddiness and decreased respiratory effort in one subject at 160 p.p.m. Olfactory recognition was immediate at 5 p.p.m. The maximum allowable concentration recommended by the American Conference of Governmental Industrial Hygienists is 10 p.p.m.

\section{The Chlorinated Hydrocarbons}

The narcotic action of the halogenated hydrocarbons is well recognized, while some of them can also injure the liver or kidneys. The most toxic of the whole group, tetrachloroethane, partly as a result of experience in the aviation industry during the first world war, now has a somewhat restricted industrial application.

Controversy on the toxicity of the various members of the group has mainly related to their capacity for producing liver damage, especially with chronic exposure, and in the case of trichloroethylene whether it can be regarded as a liver poison at all. Many French investigators are convinced that trichloroethylene is not so innocuous in this respect as has hitherto been believed; nor do some of them agree that perchloroethylene, regarded by most authorities as one of the least toxic chlorinated hydrocarbons, should be considered a harmless substitute for trichloroethylene.

Trichloroethylene.-Trichloroethylene is a colourless liquid with a not unpleasant odour [B.P., (technical variety, 86.2 to $87 \cdot 2^{\circ} \mathrm{C}$., stabilized, 86 to $88^{\circ} \mathrm{C}$., sp. gr. 1.469 to 1.475 ]. It vaporizes easily at ordinary temperatures, and is not inflammable, but under the influence of strong light or catalysts, such as aluminium dust, may decompose, with formation of $\mathrm{HCl}$, and in contact with a naked flame may give rise to phosgene. Its industrial uses cover a wide field, particularly as a degreasing and cleansing agent.

Toxicity.-The question of trichloroethylene intoxication has received much investigation in recent years and many authorities consider that it should be placed higher in the list of toxic chlorinated hydrocarbons than its threshold limit value of 200 p.p.m. would indicate.

Effects on the Nervous System.-The acute narcotic effects of trichloroethylene have always been recognized; its powerful anaesthetic properties have in fact been widely used in surgical practice. It is on the question of its chronic effects that dispute has arisen. The numerous symptoms attributed by Stüber (1931) to chronic intoxication have been to some extent discounted by other observers, partly on the hypothesis that the trichloroethylene used in her investigations contained impurities which may have been responsible for some of the disturbances 
listed. An investigation in 1955 by Grandjean et al., however, revealed a high incidence of neurological disturbances, including nystagmus, modification of vision and of sensory reflexes, slow tremors, and ataxia in 14 of 50 workers examined; vegetative disorders (excessive perspiration, fine tremors, functional gastro-intestinal, and circulatory disorders) in 18, and psychical disturbances in eight. These symptoms were present when the air concentrations varied between 20 and 80 p.p.m.

Effect on the Liver.-There has always been some debate on the question whether trichloroethylene is a liver poison, and the majority opinion has been that it differs from the other chlorinated hydrocarbons in this respect. In the few cases where trilene anaesthesia has been followed by liver damage (Herdman, 1945; Dodds, 1945) it has been suggested that the cause was not trilene itself but decomposition products formed in the closed circuit machine with a soda lime absorber. In a fatal case reported in the Lancet (1944), in a child of 2 years, however, in spite of the fact that the anaesthetic was given by an open mask, the liver showed central necrosis similar to that seen in delayed chloroform poisoning. Evidence of liver disease after ingestion of trichloroethylene has recently (1956) been reported by Lamotte, Caroit, and Nathan and after severe industrial exposure by Carrié, Perrault, and Bourdin (1941), and Dérobert, Hadengue, Martin, and Prachet (1952), while Germain and Marty (1947) described a fatal case of hepato-nephritis in a man who had used trichloroethylene as an addition to a paint which he had used for three and a half hours in a small room. The liver showed areas of necrosis and fatty degeneration and the kidneys severe tubular nephritis. Other French authorities have observed hepatitis in experimental animals (Fiessinger and Loeper, 1941), as also has Seifter (1944), while liver involvement has been noted in cases of acute trichloroethylene intoxication with oedema of the lung (Vallée and Leclerq, 1935) but the evidence of liver damage from chronic industrial exposure is not convincing.

The best record of an industrial case is that of Carrié, et al. (1941) in an employee of a shoe factory who developed severe jaundice and died. The liver was small, intensely bile-stained, with central necrosis and basophilic cell infiltration.

The case reported by Joron, Cameron, and Halpenny in 1955 is exceptional in attributing a fatal massive necrosis of the liver to a trichloroethylene exposure of not more than two and a half hours every two or three weeks for 18 months. The man, a chemist in a plant where trichloroethylene was used as a solvent, stated that he had always worn a mask except on one occasion, the day preceding that on which nausea and extreme fatigue became superimposed on general fatigue from which he had suffered for some months. He became jaundiced, developed ascites, and died in coma a month later. The liver showed acute necrosis with no productive fibrosis. Analysis of the air in the room where he had supervised the preparation of a solution used for processing paper, involving the mixing of trichloroethylene, paraffin, and resin, showed concentrations up to 297 p.p.m. during the mixing when doors and windows were closed and up to 200 p.p.m. when they were open.

Effects on the Blood.-Various changes in the blood picture of persons exposed to trichloroethylene have been recorded from time to time, but the consensus of opinion (with which the author, from personal observations, agrees) is that these are not specific, and do not represent a true dyshaemopoietic effect. In one of the most comprehensive recent surveys of chlorinated hydrocarbon solvents (Vallaud, Raymond, and Salmon, 1956), it is recorded that the blood picture of a number of employees exposed to tri- and perchloroethylene was remarkably constant, the only variation being a slight initial polycythaemia returning to normal within a few months. This observation has been confirmed still more recently by Guyotjeannin, Fournier, and Guyotjeannin (1958), following an investigation of 75 workers using pure trichloroethylene as a degreasing agent. These men showed trichloracetoaciduria and typical symptoms of chronic trichloroethylene intoxication (fatigue, headache, nausea, vertigo, dizziness). Only very slight, infrequent and insignificant variations of the blood picture were present in a few cases. These observers conclude that trichloroethylene is not toxic to the haemopoietic system.

Sudden Deaths in Trichloroethylene Workers."Mysterious sudden deaths" have been reported in trichloroethylene workers, usually during periods when they were not exposed and often following exertion: at necropsy no gross anatomical changes were found which could be held responsible, and several hypotheses have been advanced to account for the cause of death. Among these are primary cardiac failure, ventricular fibrillation, and anoxia due to tachypnoea and impaired alveolar ventilation. Cardiac arrhythmia causing syncope is not uncommon during inhalation of trilene for anaesthetic purposes. Such cases have been recorder by Geiger (1943) and by Waters, Orth, and Gillespie (1943), while Bernstine (1954) observed ventricular tachycardia and fibrillation in a case under trilene analgesia.

In four industrial cases where death occurred a 
short time after cessation of exposure, Kleinfeld and Tabershaw (1954) attributed the cause to cardiac arrhythmia, as also did Bell (1951) in a similar case occurring in a dry cleaning establishment. In all these cases it was found that there had been previous complaints of occasional nausea and giddiness, but actual collapse and death were sudden, either while travelling home, or, in one case, a night watchman who cleaned metal parts with trichloroethylene during his shift, unobserved during the night.

Trichloracetoaciduria.-Since Barrett and Johnston in 1939 demonstated trichloracetic acid in the urine of dogs narcotized by trichloroethylene, the quantitative aspect of the relation between trichoroethylene exposure and the amount of trichloracetic acid excreted in the urine has provided useful information as to the efficacy of the plant and ventilation in workshops where trichloroethylene is used, but the wide variations in individual excretion do not permit its being used alone without air analyses of the actual degree of exposure. Powell (1945), and Paykoc and Powell (1945) followed up the animal experiments by identifying trichloracetic acid in the urine of human beings anaesthetized by trilene, and showed that its elimination was slow; this observation has since been confirmed by other observers, including Grandjean et al. (1955), who found considerable amounts of trichloracetic acid in the urine up to 10 days after exposure.

From these observations attempts have been made to relate the amount of trichloracetic acid in the urine to the level at which exposure to trichloroethylene can be injurious. The ratio between the urinary trichloracetic acid excretion and the exposure to trichloroethylene was found by Grandjean to vary somewhat with age, the younger workers having an average ratio of $6: 1$, the older men $2: 1$, the average for men occupied for the whole day on a trichloroethylene plant being 3:1. It was found that about $13 \%$ of the trichloroethylene inhaled during a work period of eight hours was eliminated as trichloracetic acid. (An investigation of workers in dry cleaning establishments by Bardoděj and Krivucová in 1955 gave a figure of 5 to $8 \%$.)

Correlation between the appearance of symptoms and the urinary concentration of trichloracetic acid has been postulated by some observers but not confirmed by others. Ahlmark and Forssman (1951) found such a correlation and suggested that the limit of tolerance of excretion of trichloracetic acid should be fixed at $20 \mathrm{mg}$. per litre, corresponding to an exposure to trichloroethylene concentrations of 5 to 10 p.p.m. Grandjean et al. found symptoms appearing with an average air concentration of 40 p.p.m. Hickish, Smith, and Bedford (1956), investi- gating the atmospheric exposure, urinary trichloracetic acid, and clinical findings in three employees on a degreasing plant found that at various positions the concentrations of trichloroethylene vapour varied from 62 to 637 p.p.m., the 24-hour urinary excretion of trichloracetic acid from 175 to $258 \mathrm{mg}$. per litre, and that at these levels vague symptoms of fatigue, headache, and occasional vertigo, with no detectable clinical organic disturbance, were present. Correlation of symptoms with trichloracetic acid excretion has not been confirmed by Frant and Westendorp (1950) or by Bardodéj Vyskočil (1956), but the use of the amount of trichloracetic acid in the urine as a criterion of the actual amount of exposure seems to have found favour in many quarters. A simple field test for this purpose has been described by Engel (1956). His test for trichloracetic acid was based on the Fujiwara reaction as described by Frant and Westendorp in 1950 , and modified by Waldman and Krause in 1952, using a spectrophotometer. In Engel's method a Lombard colorimeter with a series of standard coloured discs is used and the results are read in milligrams per litre in nine stages from 12.5 to 200 mg. per litre. The present maximum allowable concentration of trichloroethylene suggested by the American Conference of Governmental Industrial Hygienists in 1958 is 200 p.p.m., a value far above that of 5 to 10 p.p.m. (corresponding to a trichloracetic acid excretion of $20 \mathrm{mg}$. per litre) suggested by Ahlmark and Forssman, or the 40 p.p.m. (corresponding to a trichloracetic acid excretion of 96 mg. per litre) by Grandjean et al. The only countries where such low levels of air concentrations of trichloroethylene are actually insisted upon are Russia and Czechoslovakia, where the limit is 9 p.p.m.

Perchloroethylene. - Perchloroethylene (tetrachloroethylene, ethylene tetrachloride) has until recently been regarded as one of the least toxic of the halogenated hydrocarbons, especially with respect to its action on the liver, and has been proposed as a substitute for trichloroethylene, but some recent investigations seem to indicate that this view of its relative non-toxicity may be unfounded.

Perchloroethylene is a colourless, non-inflammable liquid with a slight ether-like odour (B.P. $121^{\circ} \mathrm{C}$., sp. gr. 1.610). It is used chiefly as a degreasing agent but also as a dry cleaner.

Toxicity.-As a narcotic agent perchloroethylene is slightly more powerful than trichloroethylene (Lazarew, 1929).

In animals both single and long-continued exposures to high concentrations (up to 2,300 p.p.m.) 
have produced only slight liver damage (Lamson, Robbins, and Ward, 1929; Carpenter, 1937). In human beings few cases of acute injury which could be definitely attributed to perchloroethylene have been recorded. A case of fatal hepato-nephritis with pulmonary oedema was reported by Vallaud et al. in 1956, but the conditions were not precisely described, and another, by Beyer and Gerbis, in 1931, in which the cause of death was stated to be liver degeneration, was of doubtful origin as perchloroethylene was not the only constituent of the drycleaning solvent used. A fatal case recorded by Lob, in 1957, in conjunction with his description of other slighter cases of intoxication in the same factory, is more definitely attributable to perchloroethylene. The fatal case was of a builder employed in installing vacuum exhaust for a perchloroethylene plant; after being seized with nausea and faintness he died suddenly. The cause of death was pulmonary oedema. Two other workers on the plant showed severe neurological disturbance similar to that reported from chronic trichloroethylene intoxication, including tremors, disturbance of equilibrium, difficulty in walking, and abnormal sensory reactions. Seven others, after being employed from three weeks to eight months, complained of less severe symptoms-weakness, dizziness, headache, nausea, vomiting, anorexia, and irritability-which disappeared on stopping work. The air concentrations of perchloroethylene were found to be about 75 p.p.m. A similar syndrome was noted by Coler and Rossmiller, in 1953, in workers engaged in degreasing metals twice a week, where the air concentrations were 230 to 380 p.p.m. These workers showed in addition slight changes in hepatic function.

It is concluded that perchloroethylene, if used as a substitute for trichloroethylene, which has the same threshold limit value (200 p.p.m.), must be used with the same precautions.

Carbon Tetrachloride (Tetrachloromethane) $\mathbf{C C l}_{4}$. -Carbon tetrachloride is a colourless, non-inflammable liquid with an odour rather like that of chloroform (B.P. 75.7 to $76.7^{\circ} \mathrm{C}$., sp. gr. 1.600 to 1.608). Carbon tetrachloride has found a wide application during recent years in the manufacture of refrigerants and as an insecticide dispersant; its use as a dry-cleaning agent has decreased considerably, but it is still used extensively as a fire extinguisher.

Toxicity.-The acute effects of carbon tetrachloride poisoning-narcosis, liver and kidney injury-are so well known and the means of preventing them in industrial processes so widely recognized that they have become much less frequent of late years. It is evidently realized, from the fact that the threshold limit value has been reduced from 100 p.p.m. to 25 p.p.m. that the quantities likely to produce toxic effects on the liver and kidneys are not so great as was formerly believed. The account (Occupational Health News, 1956) of a nonindustrial fatality, when only about 1 pint of $\mathrm{CCl}_{4}$ had been used to clean a carpet in an apartment, whose owner died $\mathbf{1 0}$ days later from toxic hepatitis and renal insufficiency, is a reminder that susceptible persons may respond adversely to concentrations considerably lower than those once regarded as the safety limit for acute poisoning; as late as 1931 the Retail Credit Company of Atlanta suggested 1,600 p.p.m. as a safe level for short-term exposure. The actual concentration in the room in which the above case occurred was 63.5 p.p.m. Whatever the route of administration, most fatal cases develop symptoms after a delay of one to three days and survive a week or more. The damage to internal organs is usually most marked in the liver; in other cases the kidneys are more severely affected, and in all there is some lung involvement.

The actual mechanism of the liver injury, and the processes of regeneration have been described by several observers. Its connexion with enzymatic activity has been investigated by Christie and Judah (1954) and, with the help of paper chromatography, by Wahi, Tandon, and Bharadwaj (1955). It appears that the primary assault by carbon tetrachloride on the mitochondria of the liver cell causes enzymatic disorganization and initiates changes in protein metabolism, with conversion of cellular proteins to amino-acids. If these changes are so marked that the cell cannot survive, necrosis follows and autolysis of the necrosed cells causes a further rise in free aminoacid concentration. In other cells, particularly those at the periphery, the alterations are less marked, and, if minimal, recovery soon follows. This process of recovery and the capacity of the liver for regeneration when exposure has ceased was the basis of the view expressed by Stewart and Witts in 1944 that the gastro-intestinal symptoms in many persons exposed to small repeated doses of carbon tetrachloride were not indicative of permanent liver injury. They pointed out that if each dose is too small to produce an initial tissue lesion, repeated exposure, however often repeated, will not cause hepatic damage, and that in animals at any rate, even when the liver damage has progressed perceptibly, the process may be reversible if exposure ceases. To bring about permanent damage there must be exposure sufficient to produce an immediate toxic effect, and the dose must be repeated at short intervals. Nevertheless, the dose required to produce the initial lesion is not large.

The importance of renal injury has also been 
emphasized in recent years, many observers considering it to be more frequently associated with inhalation of carbon tetrachloride than liver damage, which is predominant in cases of poisoning by ingestion (Simon, 1939). Umiker and Pearce (1953) believe that whereas the usual cause of death during the first week is hepatic failure, renal insufficiency with uraemia is the essential feature of deaths occurring after this time. The oliguria which develops within two to eight days of acute exposure is explained (Sirota, 1949) by back diffusion of the glomerular filtrate across the damaged tubule walls; in prolonged oliguria or anuria there is a marked diminution in renal blood flow, the resulting anoxia, together with the initial toxic effect, causing maximum depression of tubular function (Kirkpatrick and Sutherland, 1956). The presence of protein and blood in the urine suggests abnormal glomerular permeability. Complete recovery in favourable cases is associated with re-establishment of the tubular barrier and active epithelial regeneration of the affected nephrons; in such cases there appears to be no residual renal lesion.

Trichloroethane (Methyl Chloroform).-Trichloroethane, which has not hitherto been widely used in industry, is now being strongly recommended as a substitute for other better known solvents such as trichloroethylene, tetrachloroethylene, and especially carbon tetrachloride, partly because of its technical advantages, partly because of its alleged relative non-toxicity. This latter claim is based largely on the results of animal tests, and has been accepted in several countries. In Pennsylvania, following two cases of carbon tetrachloride poisoning, one of which proved fatal, a large electrical firm has recommended the use of a number of substitutes, containing methyl chloroform in varying proportions, for degreasing and cleansing purposes. One of these (" penetone 602 ") is a mixture of 25 to $30 \%$ of methyl chloroform with mineral spirit; another (" dynasol ") consists of $94 \%$ methyl chloroform and $6 \%$ inhibitor.

There are two isomers of trichloroethane, the $\alpha$ or 1.1.1-trichloroethane and the $\beta$ or 1.1.2-compound. Both are liquids, the $\alpha$ isomer boiling at $74 \cdot 1^{\circ} \mathrm{C}$. and the $\beta$ isomer at $113.5^{\circ} \mathrm{C}$. Trichloroethane is not inflammable and may be used without decomposition in the absence of air and water at temperatures up to $110^{\circ} \mathrm{C}$. (McGovern, 1943). In contact with water it hydrolyses appreciably at its boiling point. The National Safety Council (1957) advises that it should not be used as a fire extinguisher since irritating and toxic gases may be produced in contact with flame, though less phosgene is produced than with carbon tetrachloride.
Trichloroethane is a solvent for oils, waxes, tars, many resins, alkaloids, and rubber, and is specially suitable for cleaning and degreasing, in which operations it shows a great similarity to $\mathrm{CCl}_{4}$. Like $\mathrm{CCl}_{4}$ it is miscible with alcohol, ether, acetone, and benzene; it also mixes with $\mathrm{CCl}_{4}$. The technical grade will react violently with unoxidized aluminium and other metals, but this property has been eliminated from the stabilized forms.

Toxicity.-There is some disagreement about the relative toxicity of the two isomers. Lehmann and Flury (1943) stated that the $\alpha$ isomer was four times as toxic as the $\beta$ isomer, but this has been denied by other observers (Adams, Spencer, Rowe, and Irish, 1950) and by Dr. Hecht, toxicologist of the Farbenfabriken Bayer (personal communication from Dr. Soehring of the Pharmacological Institute, Hamburg). Dr. Hecht states categorically that " the $\beta$ isomer is certainly more toxic than the $\alpha$ isomer; the contrary opinion of Flury-Lehmann is wrong ". According to Lehmann both derivatives cause, in animals, irritation of the nervous system, some fatty deposition in the liver and kidneys, and oedema and haemorrhage of the lungs. Adams et al. (1950), however, also on the basis of animal experiments, state that trichloroethane is much less toxic than tri- or perchloroethylene, and about equal in toxicity to methylene chloride, which in its turn is considered about one tenth as toxic as carbon tetrachloride. The National Safety Council (1957), while stating that "there is no known case of human injury", affirms that " the symptoms of poisoning in order of increasing severity are impaired coordination, dizziness, sleepiness, mental dullness, and unconsciousness ". Dermatitis and eye irritation may be produced by contact; the odour at 500 p.p.m. is perceptible but not disagreeable to most persons, and 1,000 p.p.m. can be tolerated occasionally for periods up to 30 minutes. The threshold limit value of trichlorethane is given as 500 p.p.m. as compared with 25 p.p.m. for carbon tetrachloride, and according to the Hygienic Guides Committee, general ventilation is sufficient for brief exposures or those resulting from very small quantities of the solvent: with prolonged exposure to high temperature operations exhaust ventilation is required.

\section{The Ketones}

The ketones have generally been regarded as having no significant toxic effect apart from their narcotic properties when inhaled in high concentrations, and with the exception of isophorone, their place in the list of threshold limit values seems to confirm this view. Most of them range from 100 p.p.m. (methyl butyl "hexanone"), to 1,000 p.p.m. (acetone), but the level suggested for iso- 
phorone is 25 p.p.m. It appears, however, that when used in combination, the synergistic effect may produce higher toxicity than that of one ketone used alone. Smith and Mayers (1944) have reported that acetone and methyl ethyl ketone in combination may have an effect on the central nervous system which outweighs that of either; such a combination has caused acute intoxication in two cases in the United States during the manufacture of waterproof material (Industrial Accident Prevention Bulletin, 1946 vol. 14, (132), p.2).

Isophorone.-Isophorone has become a widely used solvent in the lacquer and plastics industry since its introduction in 1940, and is recognized as one of the most powerful solvents of the ketone series for nitrocellulose and polyvinyl resins.

Isophorone (isoacetophorone, 3, 5, 5-trimethyl-2cyclohexene-1-one) is a liquid with a peppermint-like odour (B.P. $215 \cdot 2^{\circ} \mathrm{C}$., sp. gr. 0.9229).

Toxicity.-While isophorone has caused no recorded injury in human beings from its industrial use apart from irritation of mucous membranes at a level of 25 p.p.m. (Silverman, Schulte, and First, 1946) it appears to produce in animals a cumulative injury to the kidneys. Repeated inhalation of concentrations above 100 p.p.m. caused the death of 12 to $45 \%$ of the animals, and though only those exposed to 500 p.p.m. showed albuminuria, the kidneys of others showed congestion, and the lungs were also affected, with desquamation of bronchial epithelium, microscopic haemorrhage, and sometimes pneumonia. A colorimetric method for the determination of small amounts of isophorone in air, based on its reaction with phosphomolybdic acid, has recently been devised by Kacy and Cope (1955).

Di-isobutyl Ketone.-The only other ketone which has been recently investigated in detail is di-isobutyl ketone.

Di-isobutyl ketone (2-6-dimethyl heptanone-4) has a boiling point of $168 \cdot 1^{\circ} \mathrm{C}$. and specific gravity of 0.8089 . It is used chiefly as a solvent for nitrocellulose, crepe rubber, synthetic coatings, and certain resins.

Toxicity.-Up to 1953 the results of experiments on animals, though providing on the whole evidence of its relative lack of toxicity, were somewhat conflicting. An investigation in that year, including observations on human subjects, confirmed that di-isobutyl ketone, apart from slight symptoms of discomfort attributable to the narcotic properties common to all ketones, causes no significant systemic injury.

Animal Experiments.-In 1949, Smyth, Carpenter, and Weil reported that while the single oral toxicity to rats was low, inhalation of 2,000 p.p.m. for eight hours was fatal to five out of six. In the same year, however, McOmie and Anderson found that single and repeated inhalation of saturated vapours indicated a somewhat lower level of toxicity. This latter conclusion was confirmed by an extensive investigation by Carpenter, Pozzani, and Weil in 1953, their animal experiments being supplemented by observations on two human subjects. The animals were exposed for seven hours daily for 30 days to concentrations ranging from 125 to 1,650 p.p.m. No significant damage was observed at 125 p.p.m. and major damage and mortality only at 1,650 p.p.m.; in between these levels there was some increase in weight of the liver and kidneys.

Tests on Human Subjects.-Human subjects tested by Silverman et al. in 1946 for their sensory response estimated that 25 p.p.m. was the highest concentration tolerable for an eight-hour exposure. Those examined by Carpenter $e t$ al. inhaled 50 and 100 p.p.m. of the vapour of di-isobutyl ketone for three hours and showed only slight irritation of the eyes, nose, and throat. There was no significant change in pulse rate or blood pressure, and tests for urinary sugar and albumin were negative. Simple coordination tests also showed no disturbance and the only symptoms of discomfort were slight headache and giddiness on returning to fresh air. They agreed that a workroom atmosphere of 50 p.p.m. would be satisfactory, and 100 p.p.m. unsatisfactory.

\section{The Glycols and Glycol Ethers}

Ethylene glycol itself and the more toxic of its derivatives appear to have a special predilection for the kidneys, but some of the ether derivatives, notably methyl cellosolve, have been reported to affect the central nervous system, and butyl cellosolve has recently been incriminated as a haemolytic agent.

Ethylene Glycol.-Ethylene glycol, owing to its low volatility, has usually proved toxic only by ingestion, and in factories in the United Kingdom there has been little or no evidence of a toxic effect from its fumes, but some unusual manifestations following chronic exposure have been reported from Italy.

Ethylene glycol (glycol alcohol) is a clear, syrupy hygroscopic liquid with a sweetish taste (B.P. $197.85^{\circ} \mathrm{C}$., sp. gr. I.1136). It is used to some extent as a solvent for food and toilet preparations, but chiefly as an anti-freeze agent for automobile radiators.

Toxicity.-From 1930 onwards, many cases of severe poisoning, some of them fatal, have been recorded following ingestion, either accidental or 
purposeful, and in all the pathological changes have been consistently and predominantly renal. A welldocumented non-fatal case, in which biopsy of the kidney revealed the characteristic lesions, was that described by Ross in 1956 of a man who had drunk a quarter to half a pint of anti-freeze and developed not only anuria but also meningo-encephalitis. The kidney biopsy showed marked destruction of epithelial cells and deposition of calcium oxalate in the tubules. The agent responsible for this toxic effect on the kidneys is believed to be the chief metabolite of ethylene glycol, oxalic acid. The amount of this product recoverable from the urine is 3 to $10 \%$; therefore the amount derived from 100 $\mathrm{ml}$. of ethylene glycol is 3 to $10 \mathrm{~g}$., and according to Jeghers and Murphy (1945) a dose of $2 \mathrm{~g}$. of oxalic acid may be fatal.

Propylene Glycol.-This is possibly the only derivative of glycol which is believed to have no direct toxic action on the kidneys, and this has been explained by the fact that it does not form oxalic acid as a metabolite (Berman, Schreiner, and Feys, 1957).

Chronic industrial poisoning from ethylene glycol is, as already mentioned, rare, but a few cases reported in England had some albumin and red corpuscles in the urine (Browning, 1952). An unusual effect of chronic exposure was described by Troisi (1950) in a group of women engaged in the manufacture of electrolytic condensers. One phase of the work involved the spreading by hand of a mixture of $40 \%$ ethylene glycol, $55 \%$ boric acid, and 5\% ammonia. In this operation, because of the necessity to keep the receptacles at a temperature of $105^{\circ} \mathrm{C}$., exposure to the vapour of ethylene glycol was inevitable. The symptoms were those of periodic attacks of loss of consciousness, lasting only five to 10 minutes and followed by no apparent discomfort. Ten of the 38 women employed showed well-defined nystagmus, which was interpreted as being of supranuclear origin without involvement of the vestibular apparatus. Both the nystagmus and also the attacks of unconsciousness disappeared when the process was operated in a closed plant.

Methyl Cellosolve.-While methyl cellosolve has been known to cause toxic changes in the kidneys of animals by ingestion, its chief toxic effect from industrial exposure has been related to the central nervous system; it can also cause anaemia of the macrocytic variety.

Methyl cellosolve (ethylene glycol monomethyl ether, 2-methoxyethanol) is a colourless, stable liquid with a faint, not unpleasant odour (B.P. $124.5^{\circ} \mathrm{C}$., sp. gr. 0.967$)$. It is used in the lacquer industry, and as a solvent in the manufacture of
" fused collars", where the lining of cellulose acetate is soaked in a solvent containing about $33 \%$ of this substance; when heat and pressure are applied the collar becomes permanently stiffened.

Toxicity.-The principal industrial effect of methyl cellosolve recorded has been "toxic encephalopathy", with symptoms of lassitude, sleepiness, giddiness, severe frontal headache, and a change of personality from intelligence and quickness to stupidity and lethargy (Parsons and Parsons, 1938). Moderate ataxia was present in the two cases reported by these authors and also in one recorded by Donley (1936), while Greenburg, Mayers, Goldwater, Burke, and Moskowitz (1938) noted abnormal reflexes, tremor of the hands, and mental retardation. All these workers were employed in the fused collar process, and some of them showed a macrocytic anaemia.

Butyl Cellosolve.-Butyl cellosolve (ethylene glycol mono-n-butyl ether) has been indicted on the basis of animal experiments as a haemolytic agent, though it is not unique among the glycol derivatives in this respect; methyl cellosolve acetate, cellosolve, and butyl ethyl cellosolve appear to have the same propensity for causing erythrocyte fragility, but none of them appears to exert this effect strongly in human beings.

Butyl cellosolve is a colourless, mobile liquid with a slightly rancid odour (B.P. 170 to $176^{\circ} \mathrm{C}$., sp. gr. 0.9188). It is used as a solvent for cellulose nitrate, resins, oils, and fats, and to some extent as a constituent of paints and lacquers.

Toxicity.-In addition to its action as a central nervous depressant and a kidney toxin, in which respects butyl cellosolve is considered to have a high toxicity relative to other members of this group, it causes marked haemolysis in rodents, but there is a variation in toxicity according to the species of animal and a still more marked difference between animals and human beings.

In rodents, the haemolytic effect is very evident with massive inhalation (Carpenter, Pozzani, Weil, Nair, Keck, and Smyth, 1956), the haemoglobin level being halved after inhalation for seven hours, and the number of red corpuscles being reduced even further. Osmotic fragility tests show a repeated pattern of increased fragility during exposure followed by a decrease to normal values after an overnight rest. This suggests that the older and weaker cells are being destroyed and promptly replaced. The haemolytic effect is not nearly so marked in dogs (Werner, Mitchell, Miller, and von Oettingen, 1943; Werner, Nawrocki, Mitchell, Miller, and von Oettingen, 1943) and is absent in human beings exposed to 200 p.p.m. for eight hours 
whereas rats develop haemoglobinuria with 62 p.p.m. for four hours.

Metabolic studies carried out with the help of chromatography show that in animals and human beings most of the butyl cellosolve is excreted in the urine in the form of butoxyacetic acid. Human beings inhaling 195 p.p.m. for two four-hour periods with a half-hour interval excreted 175 to $300 \mathrm{mg}$. per 24-hour sample; with exposure to 100 p.p.m. for eight hours the 24-hour excretion was 100 to 200 mg. with individual variations (Carpenter et al., 1956). They believe that butoxyacetic acid is more directly responsible for the haemolytic effect than butyl cellosolve itself, and that the chief reasons for the rarity of industrial injury from this solvent are its low volatility, the slow effect on the erythrocytes of the low concentrations thus available, and the fact that this is one of the solvents to which human beings are more resistant than animals.

The present recommended threshold limit value of 240 p.p.m. appears unlikely to cause human injury, but in view of the possibility that constant and rapid replacement of haemolysed red cells might eventually prove a strain on the erythropoietic system and cause some degree of haemolytic anaemia, 100 p.p.m. might be a more appropriate level.

\section{The Propylene Glycol Methyl Ethers}

The powerful solvent capacity for nitrocellulose and synthetic resins of these members of the glycol group, and the fact that they combine the chemical properties of alcohols, ethers, and hydrocarbons has brought them into industrial prominence during recent years.

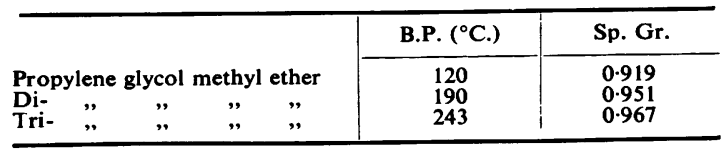

They are all miscible with water and with acetone, benzene, ether, carbon tetrachloride, methanol, and a large number of other organic solvents.

Toxicity.-The principal toxic effect of all three compounds is narcosis, the mono-compound being most active in this respect. They appear to be comparable in acute and chronic toxicity by inhalation to methyl chloroform 1.1.1. trichloroethane) and in general systemic effect to other solvents, such as trichloroethylene and perchloroethylene, which are powerful narcotics but cause relatively little organic injury. They are to some extent skin irritants and can be absorbed by the intact skin. In animals, single 24-hour applications of $10 \mathrm{ml}$. per $\mathrm{kg}$. of the mono- and $15 \mathrm{ml}$. per $\mathrm{kg}$. of the di-compound caused some deaths. Repeated exposure over a period of six months to practically saturated atmospheres was followed by only slight general ill-effects but some narcosis and minor injuries to the lungs and liver (Rowe, McCollister, Spencer, Oyen, Hollingsworth, and Drill, 1954).

In human beings no injury has been recorded from the industrial use of these solvents, and skin sensitization tests with di-propylene glycol methyl ether showed no evidence of irritation or sensitization in 250 unselected subjects. It appears that there is little likelihood of toxic amounts of these compounds being absorbed by the skin or by inhalation. In the latter case, concentrations dangerous to life would be so objectionable that they would not be breathed voluntarily, and the highest concentration of the di-compound available at ordinary room conditions is $\mathbf{3 0 0}$ to 400 p.p.m., which was tolerated by animals with very little ill-effect and is quite disagreeable to human beings.

The effects of the tri-compound have not been evaluated, but Rowe et al. state that a saturated atmosphere at room conditions (about 50 p.p.m.) could probably be tolerated without ill-effects. Dipropylene glycol methyl ether is probably the safest of the three for uses involving prolonged or repeated contact with the skin.

\section{Tetrahydrofuran}

Tetrahydrofuran (diethylene oxide), a colourless liquid with an etheric odour (B.P. 65 to $66^{\circ} \mathrm{C}$. sp. gr. 0.88 ), is one of the newer solvents which has been found to have excellent solvent properties for lacquers and resins, and so far, in spite of its chemical similarity to dioxane, there are no reports of neural damage from its industrial use, though there is some evidence of kidney injury in animals. A recent investigation by McCormick (1957) indicates that tetrahydrofuran is primarily a narcotic, no more potent than methyl ethyl ketone, and that it is safe to use in concentrations of 100 to 200 p.p.m. The skin irritation noted by Lehmann and Flury (1943) is believed (Hofmann and Oettel, 1954) to be due to decomposition products of the technical grade, such as peroxide, rather than to tetrahydrofuran itself.

\section{Amines and Coal Tar Bases}

The principal compounds of this group used as solvents are the ethanolamines, cyclohexylamine, and ethylene diamine. The ethanolamines, the tricompound of which is industrially of the most importance, are relatively non-toxic, even as skin irritants and have no significant systemic toxicity. Cyclohexylamine and ethylene diamine, however, have both been recently incriminated as sensitizers 
as well as direct skin irritants, and cyclohexylamine has been reported to cause some disturbance of health.

Cyclohexylamine (Hexahydroaniline, Aminocyclohexane).-Cyclohexylamine is a colourless, strongly basic liquid with a marked fishy odour (B.P. $134 \cdot 5^{\circ} \mathrm{C}$., sp. gr. 0.8647). It is used chiefly as a solvent for dyestuffs, as a dye intermediate, and as a vulcanizer in the rubber industry.

Toxic Effects.-Cyclohexylamine is a strong skin irritant and a moderately strong sensitizing agent (Mallette and von Haam, 1952). It is lethal to animals by injection or by inhalation of high $(1,200$ p.p.m.) concentrations (Watrous and Schulz, 1950), probably by its toxic action on the motor centres of the spinal cord and medulla (Carswell and Morrill, 1937). Systemic toxic effects of a mild and transitory character from industrial exposure have been recorded in three cases by Watrous and Schultz, in the form of drowsiness, nausea, and dilatation of the pupils, with vomiting in one case. Measurements of air concentrations showed that no symptoms arose at levels of 4 to 10 p.p.m. No threshold limits have yet been established for cyclohexylamine.

Ethylene Diamine (1,2, Diaminoethane).-Ethylene diamine is a hygroscopic liquid with an ammoniacal odour (B.P. $117 \cdot 2^{\circ}$ C., sp. gr. $0 \cdot 8895$ ). Although ethylene diamine finds its chief application in the chemical industry as an intermediate in the synthesis of organic compounds, it is also used to some extent as a solvent for water-insoluble acids, resins, and gums.

Toxicity.-Ethylene diamine is an irritant to skin and mucous membranes and can cause burns. Its chief disadvantage from the point of view of industrial exposure is its capacity for sensitization, both by skin contact and by inhalation. Like ethylene amine, a substance used chiefly as an intermediate in the textile industry, which has a similarity of chemical structure but is 40 to 100 times as toxic to animals (Carpenter, Smyth, and Schaffer, 1948), ethylene diamine has been shown to have a systemic injurious effect on animals; by subcutaneous injection (Barbour and Hjort, 1920) and by the oral and respiratory routes its effects are lethal with high dosage. Pozzani and Carpenter (1954) found that inhalation of 1,000 p.p.m. caused death of all the animals within 20 days of the initial exposure with depilation beginning on the sixth day and almost complete after 10 to 15 days. The liver and kidneys showed cloudy swelling, the kidneys some degeneration of the convoluted tubules, and the lungs some congestion. These findings were essentially the same at 500 p.p.m. but at 250 p.p.m. and below there was no significant damage to the internal organs, though there was still some slight depilation. It appears from this work that 132 p.p.m. is the level below which toxic systemic effects do not occur. A marked irritative effect on the eyes of rabbits was observed by Boas-Traube, Dresel, and Dryden (1948), and Smyth (1956) found that liquid ethylene diamine severely injured the cornea.

Blistering of the skin (Boas-Traube et al.), dermatitis, respiratory distress, and headache (Dernehl, 1951) have been observed in workmen exposed to ethylene diamine. Dernehl attributed these effects partly to direct irritation, partly to a sensitizing effect. Voluntary inhalation for short periods (5 to 10 seconds) produced slight tingling of the face and irritation of the nasal mucosa at 200 p.p.m. and severe nasal irritation at 400 p.p.m. (Pozzani and Carpenter, 1954). These observers remark that " at any concentration whatever it is to be expected that some previously sensitized persons may develop allergic responses, while the least concentration which can sensitize those not already reactive probably is indefinable". The threshold limit value for ethylene diamine suggested in 1957 is 10 p.p.m.

\section{Carbon Disulphide}

The chronic toxic effects of carbon disulphide have been for many years of greater significance in industry than the acute cerebral effects described. For example, in the Report of the Departmental Committee on Certain Miscellaneous Dangerous Trades in 1899, where it was stated that the windows of a vulcanizing room in one factory had to be barred to prevent men in a state of acute mania from leaping out. Even the well-recognized symptoms of chronic intoxication-polyneuritis, optic neuritis, Parkinson's syndrome, gastro-intestinal disturbances, and psychic changes- are now rarely observed during the course of employment in a process involving the use of carbon disulphide. Descriptions of a late syndrome of vascular origin, however, began to appear from 1942 onwards in the reports of Italian, German, and French investigators. The vascular disturbance appears to be an arterio- or atherosclerotic change in the small arteries of the brain and medulla, giving rise to a diffuse encephalopathic reaction, showing itself as hypertension or nephrosclerosis. According to von Rechenberg (1957), this syndrome, first described by Vigliani and Cazzullo in 1950, as " encephalopathia diffusa sulphocarbonica" appears only after 10 to 15 years' exposure, and once subacute symptoms have appeared is rapidly progressive. The disease has a slow, insidious onset and its development is punctuated by episodes of transient hemiplegia or spastic paresis. The fact that the sufferers are usually under 50 years of age (in a 
series of cases described by Vigliani in 1954, the average age was 43) differentiates this form of arteriosclerosis from the ordinary senile form, though the electrocardiogram shows a similar picture. Whether this sclerosis is due to an angiospastic action of carbon disulphide on the arterioles or to an interference with the metabolism of lipoproteins is not yet definitely agreed upon. Vigliani (1954) has suggested that its action might consist of an inhibition of the clearing factor in the blood, thus preventing the transformation of the more coarsely dispersed $\beta$-lipoproteins into the finely dispersed $\alpha$-lipoproteins.

The nephrosclerotic form is accompanied by hypertonia, albuminuria, microhaematuria with casts, and optic disc changes (von Rechenberg, 1957). The actual distribution of the carbon disulphide, which is not eliminated in the expired air or urine, in the various organs and tissues is not at present completely understood nor is it certain whether quantitative determination of very small amounts of $\mathrm{CS}_{\mathbf{2}}$ in the blood will have diagnostic significance in cases of possible chronic poisoning. Such determinations may, however, be of importance in investigating the mechanism of the toxic process, and until recently efforts to find accurate methods, either by extraction or by distillation, have been largely unsatisfactory.

The extraction method described by Hunter in 1940 was based on the formation of a yellow compound, copper diethyldithiocarbamate, when diethylamine and copper acetate were added to a petroleum ether extract of blood, a reaction which has also been used in the estimation of atmospheric concentrations of $\mathrm{CS}_{2}$ (Sonnenschein and Schäfer, 1953). This reaction formed the basis of an extraction method designed by Bäsing in 1952. He used crystallizable benzene as the extraction agent, and after repeated centrifuging to separate the various layers formed, the diethylamine and copper acetate were added to the benzene layer and the colour reaction determined photometrically by comparison with a known standard. The results showed on the average a loss of only $10 \%$ of $\mathrm{CS}_{2}$.

Distillation methods, attempting to expel the $\mathrm{CS}_{2}$ from blood and to absorb it in a medium suitable for colorimetric examination, have also been examined by Bäsing (1952) with a view to overcoming the unsatisfactory results of other investigators, and he has devised a method which is claimed to be simple enough to be carried out in factory or clinical laboratories. The absorptive reagent consists of diethylamine, triethanolamine, copper acetate, and ethyl alcohol, which becomes greenish-yellow to brown according to the amount of $\mathrm{CS}_{2}$ present. It is claimed that by this method very small amounts of $\mathrm{CS}_{2}$ have been accurately determined in the blood of animals subjected to inhalation.

\section{CONCLUSION}

A survey of past and present knowledge of toxic solvents reveals several outstanding features of progress and development in the continuous struggle to preserve the health of workpeople who are exposed to their potential ill-effects, at the same time making full use of the technical and commercial value of those already available and of those constantly being presented to the industrial world.

The first of these features is the ever-growing ability to judge the actual and potential toxicity of any solvent without waiting for the results of trial on the persons working with them. In the early days of rapid expansion in the field of organic solvents this was almost the only method available: if persons using a particular solvent exhibited recognizable symptoms of ill-health, or even died in the absence of accurate diagnosis of their cause, the solvent was judged to be toxic, and measures were instituted to prevent as far as possible the entry of the toxic substances into the body. Nowadays, not only have great advances been made in the problems of construction and installation of machines and in the efficacy of systems of ventilation, but, also, owing to the institution of research laboratories all over the world, it is now possible to forecast by animal experiment whether a solvent is likely to be toxic to human beings and even to determine the probable nature and site of action of its toxic effect. Once these facts are established, even though much deeper research may be needed to translate the effects of animal experiments into human experience, the first steps of prevention can be taken.

The second outstanding feature is the expansion of knowledge of the actual toxic processes within the body by means of the modern instruments of scientific research now available. The fact that metabolic investigations can now be carried out not only on animals but also on exposed human beings has shed a flood of light on the hitherto mysterious problem why one toxic solvent attacks particular organs and tissues, while another, belonging perhaps to the same chemical group, does not. These procedures have opened up the possibility of replacement of extremely toxic substances by others, equally valuable from the technical and economic standpoint but with considerably less harmful and more easily preventable effects on the organism.

A third most valuable advance is the annual publication of those values of atmospheric concentration, based on experimental research and actual human experience, below which persons 
engaged for eight hours a day in processes involving exposure to solvents can be expected to suffer no significant or permanent injury to health. By practical application of these values, aided by modern methods of estimating the concentrations in the air of workrooms, even though from time to time it may be found that the recommended values have been placed higher or lower than in the light of further experience they should have been, it is possible to keep the hazard of exposure down to a much lower level than in the days when an unpleasant odour or vague complaints of ill-health were the criteria of too high air concentrations.

Finally, there is still a long way to go before it can be said that any toxic solvent can be rendered entirely innocuous for use by human beings, but the more cases of toxic effects are reported the more will all those who are concerned with the safe use of these valuable tcols of industry be able to ensure that their potential for harm to those who use them is minimized to the fullest extent.

\section{REFERENCES}

Adams, E. M., Spencer, H. C., Rowe, V. K., and Irish, D. D. (1950). Arch. industr. Hyg., 1, 225.

Ahlmark, A., and Forssman, S. (1951). A.M.A. Arch. industr. Hyg., 3, 386.

Albahary, C. (1955). Sem. méd. prof. méd-soc., 31, 1173.

American Conference of Governmental Industrial Hygienists (1958). A.M.A. Arch. industr. Hlth, 18, 178 .
Wh.

Azouz, W. M., Parke, D. V., and Williams, R. T. (1952). Biochem. J., 50, 702 .'

Barbour, H. G., and Hjort, A. M. (1920). J. Lab. clin. Med., 5, 477. Bardodéj, Z., and Krivucová, M. (1955). čsl. Hyg., 4, 90.

, and Vyskocil, J. (1956). A.M.A. Arch. industr. Hlth, 13, 581. Barrett, H. M., and Johnston, J. H. (1939). J. biol. Chem., 127, 765 Bäsing, K. W. (1952). Z. Arbeitsmed., 2, 115.

Bell, A. (1951). N.Z. med. J., 50, 119.

Berman, L. B., Schreiner, G. E., and Feys, J. (1957). Ann. intern. Med., 46, 611.

Bernstine, M. L. (1954), A.M.A. Arch. Surg., 68, 262.
Beyer, A., and Gerbis, H. (1931). Veröf. MedVerw., 39.

Boas-Traube, S. G., Dresel, E. M., and Dryden, I. G. C. (1948) Nature (Lond.), 162, 960.

Browning, E. (1952). Med. Res. Coun. Industr. Hlth Res. Bd., Rep. No. 80 (Rev. ed. 1952).

Carpenter, C. P. (1937). J. industr. Hyg., 19, 323.

-, Pozzani, U. C., and Weil, C. S. (1953). A.M.A. Arch. industr. Hyg., 8, 377 .

- $\frac{H y g .,}{(1956), 377}$. Nair, J. H., Keck, G. A., and Smyth, H. F. Jr. (1956). A.M.A. Arch. industr. Hlth, 14, 114.

Smyth, H. F. Jr., and Shaffer, C. B. (1948). J. industr. Hyg., 30, 2 .'

Carrie, P. A., Perrault, M., and Bourdin, J. S. (1941). Arch. Mal. prof., 3,345 .

Carswell, T. S., and Morrill, H. L. (1937). Industr. Engng Chem., 29, 1247.

Christie, G. S., and Judah, J. D. (1954). Proc. roy. Soc. B., 142, 241

Coler, H. R., and Rossmiller, H. R. (1953). A.M.A. Arch. industr. Hyg., 8, 227.

Couchman, C. E., and Schulze, W. H. (1939). J. industr. Hyg., 21,

256.
Department of Scientific and Industrial Research (1939). Methods for the Detection of Toxic Gases in Industry. H.M.S.O., London.

Departmental Committee on Certain Miscellaneous Dangerous Trades (1899). Final Report. H.M.S.O., London.

Dernehl, C. U. (1951). Industr. Med. Surg., 20, 541.

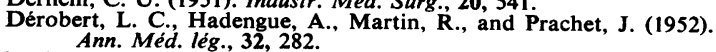

Dodds, G. H. (1945). Brit. med. J., 1, 769.

Donley, D. E. (1936). J. industr. Hyg., 18, 571

Elkins, H. B. (1954). A.M.A. Arch. industr. Hyg. 9,212 - and Pagnotto, L. D. (1956). A.M.A. Arch. industr. Hlth, 13,
Engel, H. O. (1956). Trans. Ass. industr. Med. Offrs, 6, 96. Fabre, R., Truhaut, R., and Péron, M. (1952). Arch. Mal. prof., 13,

- Bernuchon, J., and Loisillier, F. (1954). Ibid., 15, 587. Ind, L. T. (1957). Industrial Toxicology, 2nd ed. Baillière, Tindall \& Cox, London; Williams and Wilkins, Baltimore.

Fiessinger, N., and Loeper, J. (1941). Bull. Soc. méd. Hôp. Paris (Nov. 7 th).

Frant, R., and Westendorp, J. (1950). Arch. industr. Hyg., 1, 308.

Furnas, D. W., and Hine. C. H. (1958). A.M.A. Arch. industr. Hith, $18,9$.

Geiger, A. J. (1943). J. Amer. med. Ass., 123, 141

Gerarde, H. W. (1956). A.M.A. Arch. industr. Hlth, 13, 468.

Germain, A., and Marty, J. (1947). Bull. Soc. méd. Hóp. Paris, 63, 1044 .

Grandjean, E., Munchinger, R., Turrian, V., Haas, P. A., Knoepfel, H.-K., and Rosenmund, H. (1955). Brit. J. industr. Med, 12,131 .

Greenburg, L., and Moskowitz, S. (1945). Industr. Med. Surg., 14, 359, Mayers, M. R., Goldwater, L. J., Burke, W. J., and Moskowitz, S. (1938). J. industr. Hyg., 20,134

Gross, P., Schrenk, A. H., and Walmer, C. R. (1956). J. Amer. med. Ass., $161,569$.

Guyotjeannin, C., Fournier, E., and Guyotjeannin, N. (1958). Sang, 29, 338.

Herdman, K. N. (1945), Brit. med. J., 2, 689.

Hickish, D. E., Smith, J. H., and Bedford, J. (1956). Brit. J. industr. Med., $13,290$.

Hine, C. H., Ungar, H., Anderson, H. H., Kodama, J. K., Critchlow, J. K., and Jacobsen, N. W. (1954). A.M.A. Arch. industr. Hyg., 9, 227.

Hofmann and Oettel (1954). Naunyn-Schmiedeberg's Arch. exp. Path. Pharmak, 222, 233.

Hubbard, B. R., and Silverman, L. (1950). Arch. industr. Hyg., 2, 49.

Hunter, A. W. (1940). J. industr. Hyg., 22, 231.

Jeghers, H., and Murphy, R. (1945). New Engl. J. Med., 233, 208.

Joron, G. E., Cameron, D. C., and Halpenny, G. W. (1955). Canad. med. Ass. J., 73, 890.

Kacy, H. W., and Cope, R. W. (1955). Amer. industr. Hyg. Ass. Quart., 16, 55.

Kirkpatrick, H. J. R., and Sutherland, J. M. (1956). J. clin. Path., 9,242 .

Kleinfeld, M., and Tabershaw, I. R. (1954). A.M.A. Arch. industr. Hyg., 10, 134.

Lamotte, M., Caroit, M., and Nathan, J. K. (1956). Sém. Hôp. Paris, 32, 913 .

Lamson, P. D., Robbins, B. A., and Ward, C. B. (1929). Amer. J. Hyg., 9, 430.

Lancet (1944), 1, 476, [Annotation.]

Lazarew, N. W. (1929). Naunyn-Schmiedeberg's Arch. exp. Path.

Pharmak., 141, 19.
Lehmann, K. B., and Fiury, F. (1943). Toxicology and Hygiene of Industrial Solvents. Williams and Wilkins, Baltimore.

Lob, M. (1957). Arch. Gewerbepath. Gewerbehyg., 16, 45.

Mallette, F. S., and Haam, E. von (1952). A.M.A. Arch. industr. Hyg., 5, 311 .

McCollister, D. D., Beamer, W. H., Atchison, G. J., and Spencer, H. C. (1951). J. Pharmacol. exp. Ther., 102, 112.

McCormick, W. E. (1957). Industr. Med. Surg., 26, 271.

McGovern, E. W. (1943). Industr. Engng Chem., 35, 1230

McOmie, W. A., and Anderson, H. H. (1949). Univ. Calif. Publ. Pharmacol., 2, 217.

National Safety Council (1957). Data Sheet D. 456. Nat. Safety News, 76, 134 .

Occupational Health News (1956). A.M.A. Arch. industr. Hlth, 13, 212.

Ovrum, Per (1956). Brit. J. industr. Med., 13, 210.

Parke, D. V., and Williams, R. T. (1953). Biochem. J., 54, 231.

Parsons, C. E., and Parsons, M. E. M. (1938). J. industr. Hyg., 20,

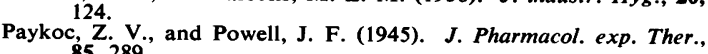

Popják, G. (1950). Biochem. J., 46, 560

Powell, J. F. (1945). Brit. J. industr. Med., 2, 142

Pozzani, U. C., and Carpenter, C. P. (1954). A.M.A. Arch. industr. Hyg., 9, 223. Rechenber,, H. K von (1957). Arch. Gewerbepath. Gewerbehyg., 15 ,

Ross, I. P. (1956). Brit. med. J., 1, 1340.

Rowe, V. K., McCollister, D. D., Spencer, H. C., Oyen, F., Hollingsworth, R. L., and Drill, V. A. (1954). A.M.A. Arch. industr.

Savilahti, M. (1956). Arch. Gewerbepath. Gewerbehyg., 15, 147.

Seifter, J. (1944). J. industr. Hyg,, 26, 250.

Silverman, L., Reece, G. M., and Drinker, P. (1939). Ibid., 21, 270.

Simon, Schulte, M. F., and First, M. W. (1946). Ibid., 28, 262.

Simon, M. A. (1939). Canad. med. Ass. J., 41, 580.

Sirota, J. H. (1949). J. clin. Invest., 28, 1412.

Smith, A. R., and Mayers, M. R. (1944). Industr. Hyg. Bull. N.Y. State Dept. Labor, 23, 174. 
Smyth, H. F. Jr. (1956), The Interpretation of Threshold Limits for Inhalation of Chemical Substances. Mellon Institute of Industrial Research, Pittsburgh. (Cited by Fairhall, L. T. 1957.)

_-, Carpenter, C. P., and Weil, C. S. (1949). J. industr. Hyg., 31, 60.

Sonnenschein, W., and Schäfer, K. (1953). Z. Anal. Chem., 140,

15.
Stewart, A., and Witts, L. J. (1944). Brit. J. industr. Med., 1, 11.

Strafford, N. (1949). Proc. 9th Internat. Congr. Industr. Med. London, 1948, p. 158

Stüber, K. (1931). Arch. Gewerbepath. Gewerbehyg., 2, 398.

Talvitie, N. A. (1958). A.M.A. Arch. industr. Hlth, 17, 563.

Tara, M. S. (1953). Arch. Mal. prof., 14, 494

Tiselius, A. (1943). Ark. Kemi. Min. Geol., 16A, No. 18. (Cited by Ovrum, Per, 1956.)

Treon, J. F., Crutchfield, W. E. Jr., and Kitzmiller, K. V. (1943). J. industr. Hyg. 25, 199, and 323.

Troisi, F. M. (1950). Brit. J. industr. Med., 7, 65.

Truhaut, R. (1953a). Ann. pharm. franc., 11, 46.

Truhaut, R. (1953a). Ann. pharm. franc.

Umiker, W., and Pearce, J. (1953). A.M.A. Arch. Path., 55, 203.
Ungar, H., Hine, C. H., Kodama, J. K., and Anderson, H. H. (1955), Ibid., 60, 139.

Vallese C., 6o, leciercq, J. (1935), Ann. Méd. lég, 10.

Valle, A Res Solvants chlorés et l'Hygiène Industrielle. Inst. Nat. Securité, Paris.

Vigliani, E. C. (1954). Brit. J. industr. Med., 11, 235.

Wahi, P. N., Tandon, H. D., and Bharadwaj, T. D. (1955). Acta path. scand., 37, 315

Waldman, A. K., and Krause, L. A. (1952). Occup. and Hlth, 12, 110

Waters, R. M., Orth, O. S., and Gillespie, N. A. (1943). Anesthe-

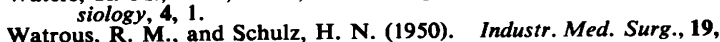
317.

Werner, H. W., Mitchell, J. L., Miller, J. W., and Oettingen, W. F.

Werner, H. W., Mitchell, J. L., Miller, J. W., and
von (1943). J. industr. Hyg., 24, 157 and 409.
Nawrocki, C. Z., Mitchell, J. L., Miller, J. W., and Oettingen, W. F. von (1943). Ibid., $25,374$.

Wolf, M. A., Rowe, V. K., McCollister, D. D., Hollingsworth, R. L. and Öyen, F. (1956). A.M.A. Arch. industr. Hlth, 14, 387.

Yant, W. P., Schrenk, H. H., Sayers, R. R., Horvath, A. A., and Reinhart, W. H. (1936). Ibid., 18, 69.

\section{THE OCTOBER (1958) ISSUE}

The October (1958) issue contains the following papers:-

Cancer of the Lung and Nose in Nickel Workers. By Richard Doll.

Some Observations on the Incidence of Respiratory Cancer in Nickel Workers. By J. Gwynne Morgan.

The Pathology of the Lungs in Five Nickel Workers. By W. Jones Williams.

Chronic Chloroform Intoxication. By P. J. R. Challen, D. E. Hickish, and Joan Bedford.

Counting Errors due to Overlapping Particles in Thermal Precipitator Samples. By S. A. Roach.

Respiratory Function of Witwatersrand Gold-miners. By Saul Zwi and Margaret R. Becklake.

A Statistical Study of Coal-mining Accidents. By F. D. K. Liddell and Joan May.

Aseptic Necrosis of Bone in Caisson Disease. By John D. Thomson and Andrew B. Young.

Some Notes on the Effects of Excessive Noise on the Hearing of a Group of Workers. By G. F. Keatinge and S. Laner.

An Investigation of Some Health Hazards in an Inert-gas Tungsten-arc Welding-shop. By P. J. R. Challen, D. E. Hickish, and Joan Bedford.

he Estimation of Gaseous Acid in Domestic Premises. By J. J. Phair, R. J. Shephard, G. C. R. Carey, and M. L. Thomson.

Quarry Bank Mill: I. The Story of the Mill. By Robert Murray.

Book Reviews.

Index to Volume 15.

A number of copies are still available and may be obtained from the Publishing Manager, British Medical Association, Tavistock Square, W.C.1, price 17s. $6 d$. 